\title{
Media Compact Disk Interaktif Berbudaya Sehat untuk Meningkatkan Kosa Kata Anak Usia Dini
}

\author{
Swantyka Ilham Prahesti ${ }^{1}$, Himmah Taulany ${ }^{2}$, Syifa Fauziah $^{3}$ \\ Pendidikan Guru Pendidikan Anak Usia Dini, Universitas Ngudi Waluyo
}

\begin{abstract}
Abstrak
Tujuan penelitian ini yaitu menentukan perbedaan hasil belajar pengembangan menggunakan media pembelajaran CD interaktif dan media konvensional. Penelitian ini menggunakan pendekatan kuantitatif dengan desain penelitian eksperimen tipe nonequevalen control group design. Simpulan penelitian ini adalah: media CD Interaktif Kosa Kata Berbudaya Sehat dapat meningkatkan kosa kata pada anak usia 5-6 tahun, dibuktikan dengan hasil nilai thitung $=$ 11,691 dengan $\mathrm{t}_{\text {tabel }}=-2,045$, ada perbedaan rata-rata sebelum dan sesudah dilaksanakan penelitian pada kelompok 1; media konvensional untuk meningkatkan kosa kata pada anak usia 5-6 tahun, dibuktikan dengan hasil nilai $t_{\text {hitung }}=11,691$ dengan $t_{\text {tabel }}=-2,045$, ada perbedaan rata-rata hasil pretes dan postes kelompok 2; Hasil belajar kosa kata menggunakan media CD Interaktif lebih besar dari pada Hasil Belajar kosa kata menggunakan media konvensional dibuktikan melalui uji $\mathrm{t}$ Independent bahwa data postes antara kelompok 1 dan kelompok 2 adalah $\mathrm{H}_{0}$ ditolak karena memiliki nilai $\mathrm{t}_{\text {hitung }}=9,863$ dengan $\mathrm{t}_{\text {tabel }}=-2,048$.
\end{abstract}

Kata Kunci: anak usia din; cd interaktif; kosa kata; media pembelajaran

\begin{abstract}
The purpose of this research is determine the difference in development learning outcome using interactive $\mathrm{CD}$ learning media and conventional media. The experimental research design used was non-equivalent control group design. The conclusion of this study was media Interactive CD Vocabulary Healthy Cultivation can increase vocabulary in children aged 5-6 years, evidenced by the results of the value of tcount $=11,691$ with $t$ table $=-2,045$, this indicates there is a difference in the average before and after the study in group 1; conventional media to increase vocabulary in children aged 5-6 years was proven by evidenced by the result of the $t_{\text {count }}=11,691$ with $t_{\text {table }}=-2,045$, this indicates that there is difference in the average result of the pre-test and post-test group 2; vocabulary learning outcome using an interactive $\mathrm{CD}$ is greater than the result of vocabulary learning using conventional media. It is proven through independent $\mathrm{t}$ test that post-test data between group 1 and group 2 is $\mathrm{H}_{0}$ rejected because it has a value of $t_{\text {count }}=9,863$ with $t_{\text {table }}=-2,048$.
\end{abstract}

Keywords: early childhood; interactive cd; vocabulary; learning media

Copyright (c) 2019 Swantyka Ilham Prahesti, Himmah Taulany, Syifa Fauziah

$\triangle$ Corresponding Author :

Address : Jl. Diponegoro 186 Ungaran Barat, Kab. Semarang ISSN 2356-1327 (Media Cetak)

Email : swantyka05@gmail.com

ISSN 2549-8959 (Media Online) 


\section{PENDAHULUAN}

Tahap pra-operational adalah tahap dimana anak mempunyai gambaran mental dan mampu untuk berpura-pura, langkah pendek untuk menggunakan simbol (Aisyah, 2010). Jadi, anak usia TK yang masih berada pada tahap pra-operational memerlukan suatu media pembelajaran yang konkret ketika melakukan suatu kegiatan pembelajaran. Media yang dapat digunakan di TK adalah media yang aman, menarik, menyenangkan, multifungsi, serta mempunyai nilai edukasi. Media yang disediakan juga harus sesuai degan usia anak, media pembelajaran yang disediakan harus berbanding terbalik dengan usia anak. Semakin tinggi usia anak, maka media yang diberikan lebih kecil dan bila usia anak rendah, maka media yang disediakan harus lebih besar.

Anak TK dalam kegiatan mengembangkan kosa kata tidak selamanya menggunakan lembar kerja yang hanya menuntut aspek kognitif dan aspek bahasa saja, melainkan membutuhkan suatu media yang dapat digunakan sebagai aktivitas permainan. Kegiatan pada lembar kerja hanya sebatas pada mewarnai gambar, menebali objek, mencari garis (mazze), menarik garis antara bilangan dengan jumlah gambar, dan mencentang gambar yang ditugaskan. Begitu banyak kegiatan yang disajikan pada lembar kerja, namun lembar kerja sendiri belum mencukupi untuk mengembangkan kosa kata pada anak, karena untuk mengembangkan kosa kata pada anak dibutuhkan benda konkret untuk membangun pemahaman anak.

Sehubungan dengan pembelajaran kosakata anak usia dini, berikut adalah literatur yang dapat mendukung topik ilmiah (Nahdayeti, 2011) meneliti permainan menyusun huruf sesuai dengan kartu kata bergambar sebagai upaya menumbuhkan kemampuan membaca awal anak. Penelitian ini bertujuan untuk mengetahui apakah permainan menyusun huruf sesuai dengan kartu kata bergambar dapat menumbuhkan kemampuan membaca awal anak di Taman Kanak-kanak Samudera Padang. Penelitian ini berbentuk penelitian tindakan kelas yaitu ragam penelitian pembelajaran yang berkonteks kelas dengan menggunakan pendekatan kuantitatif dan kualitatif. Subjek penelitian adalah siswa Taman Kanak-kanak Samudera Padang kelompok B berjumlah 16 orang. Penelitian tindakan kelas ini dilaksanakan dalam dua siklus, dan masingmasing siklus terdiri dari tiga kali pertemuan. Berdasarkan analisis data dan pembahasan, maka hasil penelitian dapat disimpulkan bahwa permainan menyusun huruf sesuai dengan kartu kata bergambar dalam upaya menumbuhkan kemampuan membaca awal anak di Taman Kanakkanak Samudera berada pada tingkat persentase $83 \%$. Pencapaian ini menunjukkan bahwa $83 \%$ siswa Taman Kanak-kanak Samudera Padang sudah tumbuh kemampuan membaca awalnya pada kategori mampu. Persamaan dengan penelitian yang akan dilakukan berada pada kemampuan membaca awal. Perbedaan dengan penelitian yang akan dilakukan berada pada permainan kartu kata bergambar dan menggunakan metode penelitian PTK.

(Choirun, 2012) penelitian ini bertujuan untuk mengetahui pengaruh permainan dan penguasaan kosakata terhadap kemampuan membaca permulaan anak usia 5-6 tahun. Permainan yang dimaksud adalah permainan scrabble dan permainan kartu gambar sedangkan penguasaan kosakata terdiri dari penguasaan kosakata tinggi dan penguasaan kosakata rendah.Hasil penelitian menunjukkan bahwa (1) terdapat perbedaan kemampuan membaca permulaan antara 
anak yang diberikan perlakuan permainan scrabble dan anak yang diberikan perlakuan kartu gambar, (2) terdapat pengaruh interaksi antara permainan dan penguasaan kosakata terhadap kemampuan membaca permulaan, (3) anak dengan penguasaan kosakata tinggi yang diberikan perlakuan permainan scrabble memiliki kemampuan membaca permulaan lebih tinggi daripada anak yang diberikan perlakuan permainan kartu gambar, (4) anak dengan penguasaan kosakata rendah yang diberikan perlakuan permainan kartu gambar memiliki kemampuan membaca permulaan relatif sama dengan anak yang diberikan perlakuan permainan scrabble.

Mok dan Lam (2011) telah meneliti tentang penilaian Rating Scale perkembangan bahasa anak dengan menggunakan Morrow's Checklist Language Development (MLSD) and Attitude toward Reading and Voluntary Reading Behavior (ARVRB) untuk menilai perkembangan aksara anak usia dini. Penelitian mereka bertujuan untuk memvalidasi rata-rata perkembangan bahasa. Penilaian tersebut untuk menilai pengembangan literasi awal yang akan digunakan dengan anak-anak prasekolah di Hongkong. Sampel terdiri dari 2.619 anak prasekolah usia 3-5 tahun yang saat ini terdaftar di tingkat prasekolah $\mathrm{K} 1-\mathrm{K} 2$ di Hongkong. Analisis menunjukkan dua skala tersebut memiliki validitas konstruk yang kuat dan konsistensi internal, dan bahwa keduanya sesuai dengan model Rasch. Namun demikian, temuan analisis Rasch menyarankan bahwa tingkat skala pengembangan bahasa tidak menyelaras dengan baik. Kemampuan bahasa anakanak TK dalam sampel yang mana lebih mahir dari pada tingkat kemahiran yang dituntut oleh item dalam hasil skala. Disarankan agar lebih lanjut diadakan perbaikan seperti masuknya item canggih mungkin diperlukan untuk aplikasi local yang valid.

Slavin, et.al (2014) meneliti cara para pendidik menggunakan program Succes for All untuk menjangkau siswa yang beresiko dan mendorong prestasi akademis. Dideskripsikan tentang efektifitas sekolah; penggabungan, pencegahan intervensi dini, dan penilaian yang berlangsung dalam mendorong keterampilan membaca. Penelitian mereka dituangkan dalam buku yang didalamnya antara lain terdapat: panduan tentang kesiapan siswa untuk belajar melalui program prasekolah dan TK yang mendorong kecakapan awal membaca dan menulis, dan kurikulum membaca untuk setiap kelompok usia dengan informasi tambahan tentang membaca dan matematika.

Hill (2011) mengemukakan hasil eksplorasi aspek bahasa awal dan keaksaraan yang dapat memprediksi perkembangan literasi. Penelitiannya tersebut untuk mengeksplorasi berbagai prosedur assesmen yang digunakan untuk bahasa lisan, kosa kata, struktur kalimat, fonologi, membaca awal dan menulis di Australia anak usia 4-10 tahun. Artikel ini menggambarkan sebuah studi skala kecil yang menyoroti pemutusan antara bahasa lisan dan melek huruf awal dan menunjukkan bahwa belajar membaca dan menulis adalah serupa dengan belajar bahasa kedua bagi anak-anak. Artikel menunjukkan bahwa bahasa awal anakanak dan keaksaraan terbaik dapat diukur dengan menggunakan prosedur ekologis yang valid. Bentuk ekologi yang valid dipraktekkan dalam pembiasaan sehari-hari dalam kehidupan sosial. Assesmen ini tidak hanya difokuskan secara individu, anakanak membutuhkan dukungan dari guru, artefact, nilai budaya dan sistem pengetahuan.

Currenton dan Craig (2009:123-146) dalam jurnal yang berjudul "Shared- 
Reading Versus Oral Story Telling, Associations with Preshoolers Prosocial Skills and Problem Behaviours" membandingkan pengaruh antara membaca bersama dengan bercerita lisan pada anakanak prasekolah dalam keterampilan prososial dan masalah perilaku. Dalam penelitian ini mereka meneliti 33 keluarga di Amerika yang mempraktekkan membaca bersama dan bercerita lisan. SharedReading Versus Oral Story Telling merupakan praktek kegiatan membaca bersama dan praktek bercerita yang dilakukan seorang ibu terhadap anak usia dininya secara terus-menerus. Hasil dari penelitian tersebut adalah selain kedua cara tersebut dapat mengembangkan kemampuan bahasa, ternyata juga bisa menanamkan sikap perilaku yang baik.

Gonzalez et.al (2009) dalam jurnal yang berjudul "An Evaluation of Early Reading First (ERF) Preschool Enrichment on Language and Literacy Skills", memberikan bukti tambahan dari dampaknya terhadap bahasa prasekolah dan pengembangan literasi. Tidak seperti studi sebelumnya, model multilevel digunakan untuk menjelaskan korelasi antar antara puluhan siswa di kelas yang sama. Tujuan menyeluruh dari ERF adalah untuk mempersiapkan anak-anak usia prasekolah untuk masuk TK dengan bahasa, kognitif, dan keterampilan membaca yang diperlukan untuk sukses dalam membaca. Desain Penelitian ini menggunakan pretest-posttest design kuasi-eksperimental untuk membandingkan kinerja anak prasekolah berpartisipasi dalam proyek ERF dengan yang dari kelompok kontras anak-anak dari sekolah yang sama menerima instruksi khas sekolah selama tahun ketiga dari ERF pelaksanaan proyek (2007-2008). Hasil penelitian ini menunjukkan bahwa sekolah ERF dapat meningkatkan bahasa lisan, pengetahuan alfabet, dan konsep menulis.
Meskipun ulangan diperlukan, untuk meningkatkan akuisisi kosakata yang ditemukan adalah penting, terutama dalam pengetahuan kosakata pertama anak pada saat masuk TK mungkin salah satu prediktor paling kuat melalui standar hasil kelima kelas dalam membaca.Persamaan dengan penelitian yang akan dilakukan berada pada penggunakan metode penelitian eksperimen. Perbedaan dengan penelitian yang akan dilakukan berada pada evaluasi pembelajaran kemampuan literasi.

Gerde, et.al (2012) dalam jurnal yang berjudul "Writing in Early Childhood Classrooms: Guidance for Best Practices" membahas keterampilan menulis awal untuk anak usia dini. Berikut adalah definisi mengenai menulis, menulis adalah keterampilan keaksaraan muncul kritis yang meletakkan dasar untuk keterampilan keaksaraan kemudian anak-anak dan prestasi membaca. kerja terbaru menunjukkan bahwa banyak program anak usia dini menawarkan bahan anak-anak dan alat untuk terlibat dalam kegiatan menulis tetapi guru jarang terlihat pemodelan menulis untuk anak-anak atau upaya menulis perancah anak-anak. Menulis adalah kegiatan penting dalam ruang kelas anak usia dini karena mendukung integrasi bahasa dan keaksaraan muncul keterampilan penting yang meletakkan dasar untuk kemampuan membaca anakanak. Menulis adalah kegiatan mengungkapkan gagasan, pendapat dan pandangan di cetak: menulis untuk komunikasi atau penyusunan. Untuk anakanak, menulis sering bingung dengan tulisan tangan atau tulisan tangan (misalnya, membuat surat well-formed). Sayangnya, ketika orang berbicara tentang menulis di kelas anak usia dini, itu adalah kegiatan membentuk huruf yang sering adalah fokus. Meskipun berlatih pembentukan huruf adalah proses penting, 
kita tidak termasuk ini sebagai bagian dari diskusi kita menulis. Penelitian ini berfokus pada bagaimana anak-anak menggunakan tulisan untuk berkomunikasi dan mengembangkan pemahaman yang mencetak adalah sesuatu yang dibaca. Dalam laporan National Awal Melek Panel (NELP) (2008, p. Vii), menulis diidentifikasi sebagai salah satu dari enam variabel yang mewakili keterampilan keaksaraan awal yang memiliki " menengah ke hubungan prediktif besar dengan langkah-langkah selanjutnya dari pengembangan literasi. " Mengingat pentingnya menulis dalam mengembangkan keterampilan keaksaraan awal, kita dapat berasumsi menulis kegiatan akan memainkan peran sentral dalam ruang kelas prasekolah. Tujuan dari penelitian ini adalah untuk memberikan review singkat tentang apa penelitian memberitahu kita tentang menulis dan anak-anak. Ulasan ini memberikan informasi tentang perkembangan perkembangan penulisan pada anak-anak dan menawarkan saran untuk guru untuk melaksanakan kegiatan menulis di kurikulum mereka sehari-hari. Juga, saran yang diberikan untuk memperluas pengalaman menulis di kelas untuk keluarga untuk membuat sambungan rumah-sekolah yang positif. Penelitian ini menyajikan pedoman berbasis penelitian untuk merancang kegiatan menulis menarik dan bermakna bagi anak-anak. Agar anakanak untuk mengembangkan keterampilan muncul keaksaraan penting dari korespondensi surat-suara dan pemahaman bahwa cetak berkomunikasi makna bahwa orang membaca, anak-anak membutuhkan beberapa, peluang berarti untuk menulis setiap hari. Ini peluang berarti harus mencakup integrasi menulis ke dalam kegiatan kelas dan memperluas kegiatan penting ini ke rumah anak-anak. Peluang menulis disarankan akan membantu anakanak mengembangkan keterampilan keaksaraan muncul yang mereka butuhkan untuk belajar dan mengembangkan kemampuan membaca kesiapan.

Sundari (2013) meneliti metode permainan pola suku kata dan kartu kata bergambar berperan sebagai media untuk mengenalkan keaksaraan.Metode dan media yang dapat diterapkan oleh guru dalam proses pembelajaran membaca di TK salah satunya yaitu melalui metode permainan dengan media kartu pola suku kata dan kata bergambar. Oleh karena itu, penelitian ini bertujuan untuk mengetahui pengaruh metode permainan pola suku kata dan kartu kata bergambar terhadap kemampuan membaca awal siswa kelompok B6 TK Negeri 2 Yogyakarta. Subyek dalam penelitian ini adalah siswa kelompok B6 TK Negeri 2 Yogyakarta melalui metode matching sejumlah 16 siswa. Adapun teknik analisis data yang digunakan dalam penelitian ini adalah Statistic NonParametric. Berdasarkan hasil analisis data diperoleh kesimpulan: (1) ada pengaruh metode permainan pola suku kata terhadap kemampuan membaca awal dengan nilai $\mathrm{Z}=-2.585$ dan nilai $\mathrm{p}$ value $(0.010<0.05)$ siswa kelompok B6 TK Negeri 2 Yogyakarta; (2) Ada pengaruh permainan kartu kata bergambar terhadap kemampuan membaca dengan nilai $\mathrm{Z}=-2.395$ dan nilai $\mathrm{P}$ value $(0.011<0.05)$ siswa kelompok B6 TK Negeri 2 Yogyakarta; dan (3) Metode permainan dengan kartu kata bergambar lebih berpengaruh terhadap kemampuan membaca awal dengan nilai meank rank yang lebih tinggi yaitu 11.81 dibandingkan dengan metode permainan pola suku kata dengan nilai rerata sebesar 5.19 dengan nilai $\mathrm{p}$ value $(0.004<0.05)$. Peneliti dapat menyimpulkan bahwa, ada pengaruh metode permainan pola suku kata dan kartu kata bergambar terhadap kemampuan membaca awal kelompok B6 TK Negeri 2 Yogyakarta.Persamaan dengan penelitian yang akan dilakukan berada pada 
kemampuan membaca permulaan dan metode penelitian menggunakan eksperimen. Perbedaan dengan penelitian yang akan dilakukan berada pada alat permainan yang digunakan pada penelitian terdahulu dan kelompok yang dijadikan subyek penelitian yaitu kelompok B, sedangkan subyek penelitian yang akan dilakukan yaitu kelompok A.

Makna interaktif berarti terdapat komunikasi secara langsung atau interaksi secara langsung antara penerima pesan (pengguna) dengan aplikasi dalam CD. Selain itu, Daryanto (2010: 51) juga mengemukakan, "multimedia interaktif adalah suatu multimedia yang dilengkapi dengan alat pengontrol yang dapat dioperasikan oleh pengguna, sehingga pengguna dapat memilih apa yang dikehendaki untuk proses selanjutnya".

$$
\text { Wina Sanjaya (2009: }
$$

mengemukakan kelebihan CD interaktif adalah: 1). Siswa dapat belajar mandiri tidak harus tergantung kepada guru atau instruktur; 2). Siswa dapat memulai belajar kapan saja dan berhenti sesuai dengan keinginannya; 3). Materi-materi yang diajarkan dalam VCD dapat langsung dipraktekkan langsung oleh siswa; 4). Terdapat fungsi repeat yang bermanfaat untuk mengulangi materi secara berulangulang untuk penguasaan secara menyeluruh.

Berdasarkan pemahaman beberapa literatur diatas maka dapat disimpulkan bahwa kemampuan anak dalam pengembangan kosa kata sangat rendah. Dalam mengembangkan kosakata, perlunya stimulasi atau rangsangan supaya anak lebih mudah dalam menerima apa yang disampaikan oleh guru. Stimulasi atau rangsangan yang tepat diberikan kepada anak usia dini yaitu dengan menggunakan media yang sesuai dengan aspek perkembangan anak. Beberapa literatur yang sudah dipaparkan diatas sesuai dengan fokus penelitian yang akan penulis teliti dan bisa dijadikan referensi oleh penulis. Dengan demikian, penulis ingin meneliti tentang pengembangan kosa kata yang diciptakan oleh peneliti dalam bentuk CD Interaktif.

\section{METODOLOGI}

Metode penelitian yang digunakan dalam penelitian ini adalah metode eksperimen, karena penelitian ini mengujikan keabsahan suatu media pembelajaran. Penelitian eksperimen merupakan pendekatan penelitian kuantitatif yang paling penuh, dalam arti memenuhi persyaratan untuk menguji hubungan sebab-akibat (Syaodih, 2009). Dalam hal ini yang diujikan adalah media CD Interaktif.

Jenis penelitian yang digunakan dalam penelitian ini adalah penelitian eksperimen. Desain penelitian yang digunakan adalah Quasi Eksperimental Design tipe Nonequivalen Control Group Design (Sugiyono, 2010). Desain penelitian eksperimental merupakan bagian penting dalam metode penelitian eksperimental dilakukan (Seniati, 2011). Desain penelitian ini diberi pretest untuk mengetahui keadaan awal adakah perbedaan antara kelompok eksperimen dan kelompok kontrol.

\section{HASIL DAN PEMBAHASAN}

Penelitian Keefektifan Penggunaan CD Interaktif Berbudaya Sehat Untuk Meningkatkan Kosa Kata Anak Usia 5-6 Tahun meliputi beberapa tahapan yaitu:

\section{Studi Pendahuluan}

Dalam penelitian ini memerlukan studi pendahuluan yang berupa literatur, buku media pembelajaran dan online, untuk menentukan topik kosa kata yang berbudaya sehat. 


\section{Tahapan Pembuatan Media}

Dalam pembuatan media CD Interaktif ini peneliti membutuhkan ahli pembuat animasi bergambar untuk dapat mewujudkan ide, maksud dan tujuan peneliti. Berikut tahap-tahap pembuatan CD Interaktif Berbudaya Sehat:

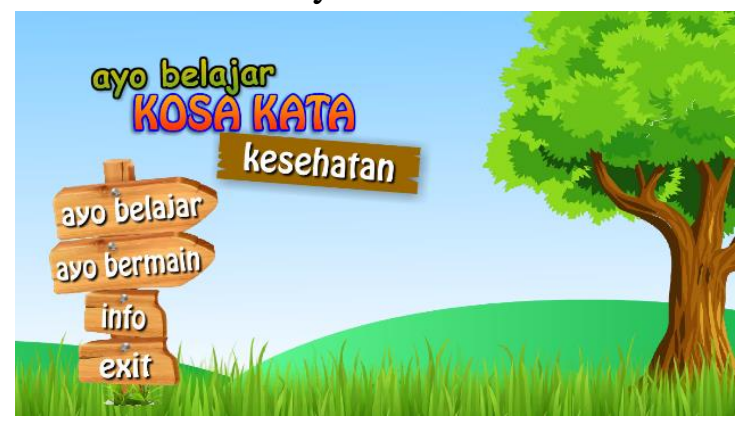

Gambar 1. Ayo Belajar Kosa Kata Kesehatan

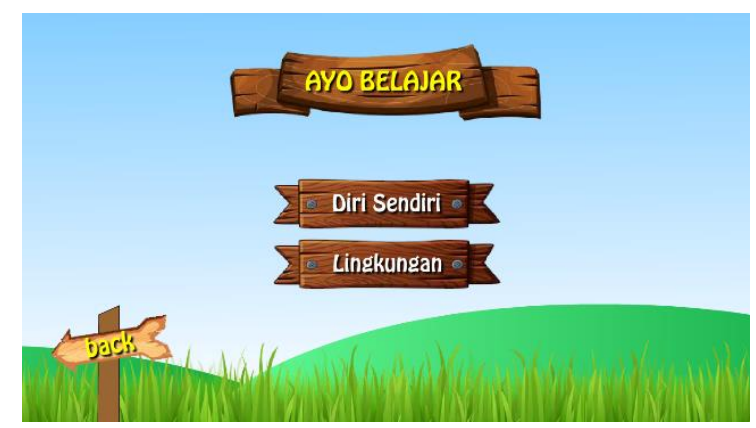

Gambar 2. Ayo Belajar

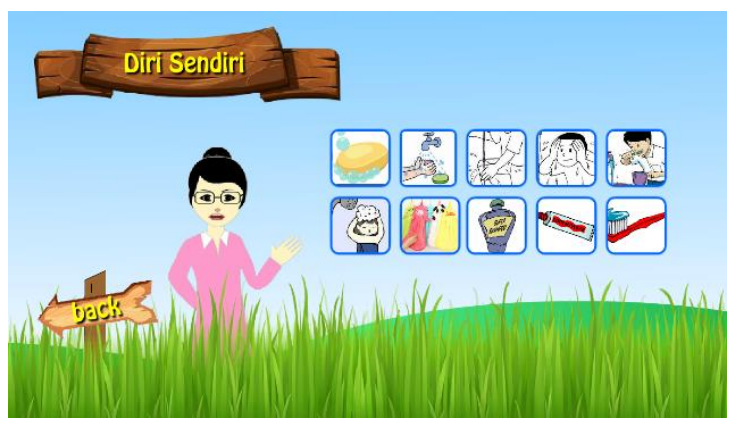

Gambar 3. Diri Sendiri

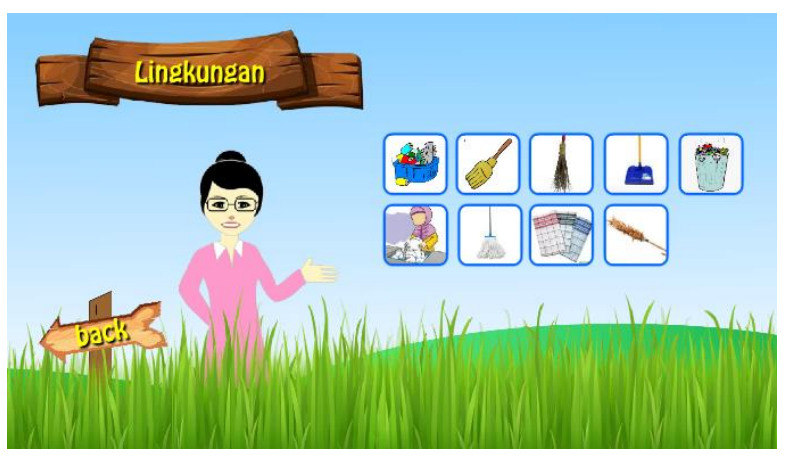

Gambar 4. Lingkungan

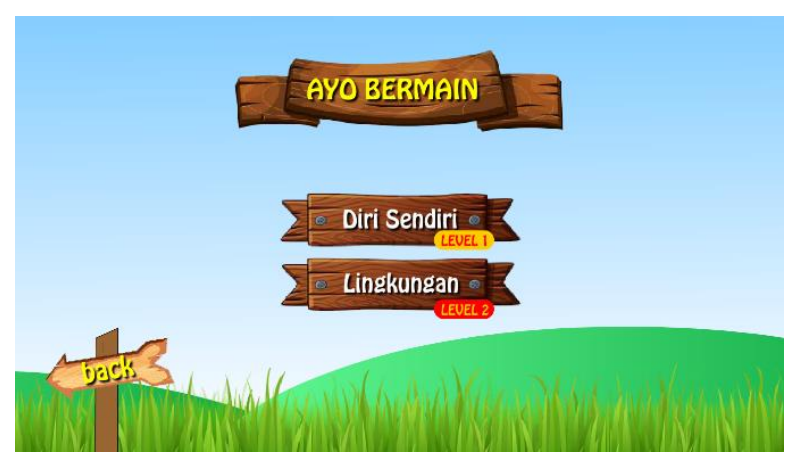

Gambar 5. Ayo Bermain

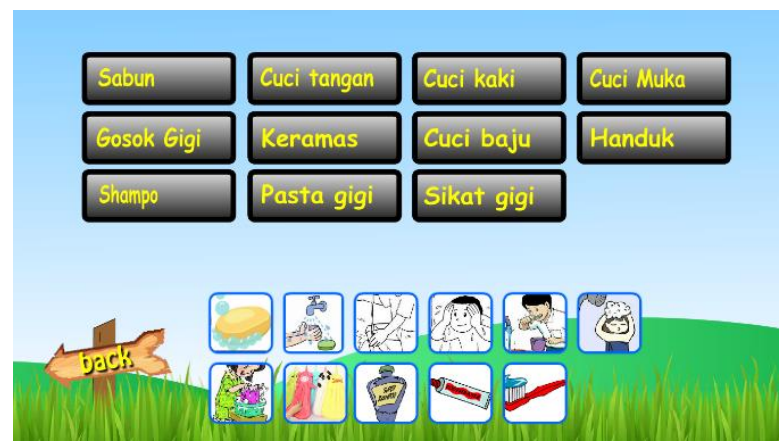

Gambar 6. Ayo Bermain (Diri Sendiri)

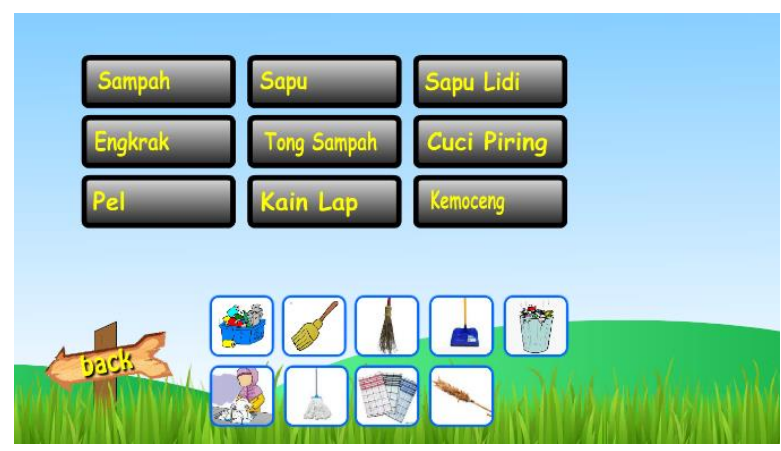

Gambar 7. Ayo Bermain (Lingkungan)

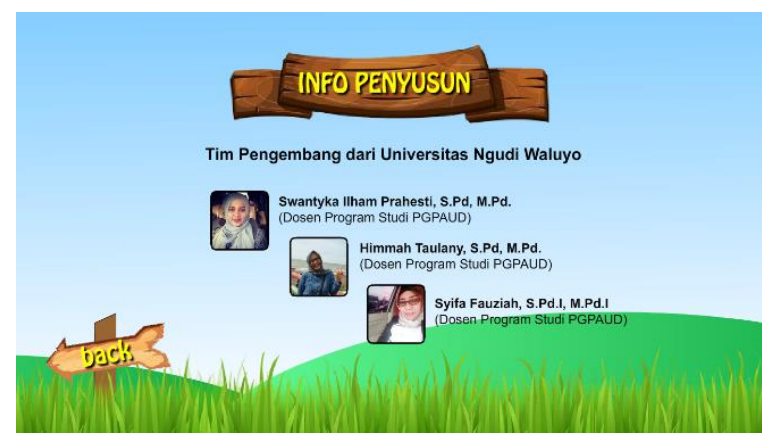

Gambar 8. Info Penyusun

Setelah pembuatan CD Interaktif, perlu adanya uji validasi ahli untuk menentukan kesiapan media tersebut. Pembuatan instrumen dalam menguji keefektifan sudah dibuat dan sudah dilakukan uji validasi ke validator ahli 
PAUD dan ahli TI. Dalam mengolah data keefektifan media CD Interaktif sudah dilakukan dan hasilnya valid. Berikut adalah hasil uji coba keefektifan penggunaan media CD Interaktif kepada anak:

\section{Hasil Pencapaian Perkembangan dengan} Media CD Interaktif Berbudaya Sehat

Hasil uji coba penggunaan media CD Interaktif Berbudaya Sehat sebelum dilaksanakan pretes memiliki rata-rata kemampuan kosa kata sebesar 17,75 poin. Setelah dilaksanakan perlakuan menggunakan media CD Interaktif Berbudaya Sehat, setelah dilakukan post test memiliki rata-rata sebesar 30,55 poin. Hasil pre test dan post test berdasarkan kriteria dapat dilihat berdasarkan Tabel1.

Tabel 1 Hasil Penggunaan Media CD Interaktif Berbudaya Sehat

\begin{tabular}{|c|c|c|c|c|c|}
\hline \multirow[t]{2}{*}{ Skor } & \multirow[t]{2}{*}{ Kriteria } & \multicolumn{2}{|c|}{ Pretes } & \multicolumn{2}{|c|}{ Postes } \\
\hline & & $\mathrm{Jml}$ & $\%$ & $\mathrm{Jml}$ & $\%$ \\
\hline 4 & $\begin{array}{l}\text { Berkembang } \\
\text { Sangat Baik } \\
(\mathrm{BSB})\end{array}$ & 0 & $0 \%$ & 6 & $20 \%$ \\
\hline 3 & $\begin{array}{l}\text { Berkembang } \\
\text { Sesuai } \\
\text { Harapan } \\
(\mathrm{BSH})\end{array}$ & 0 & $0 \%$ & 14 & $80 \%$ \\
\hline 2 & $\begin{array}{l}\text { Mulai } \\
\text { Berkembang } \\
\text { (MB) }\end{array}$ & 15 & $\begin{array}{l}60 \\
\%\end{array}$ & 0 & $0 \%$ \\
\hline 1 & $\begin{array}{l}\text { Belum } \\
\text { Berkembang } \\
\text { (BB) }\end{array}$ & 5 & $\begin{array}{c}40 \\
\%\end{array}$ & 0 & $0 \%$ \\
\hline
\end{tabular}

Hasil pengujian menggunakan uji sampel berpasangan (paired sample test) dinyatakan bahwa hasil pengujian keefektifan media CD Interaktif dalam meningkatkan kosa kata pada anak usia 5-6 tahun efektif.
Tabel 2 Hasil Uji Paired Sample Statistics Kelompok 1 Paired Samples Statistics

\begin{tabular}{|c|c|c|c|c|c|}
\hline & & Mean & $\mathrm{N}$ & $\begin{array}{c}\text { Std. } \\
\text { Deviation }\end{array}$ & $\begin{array}{c}\text { Std. Error } \\
\text { Mean }\end{array}$ \\
\hline \multirow{2}{*}{$\begin{array}{l}\text { Pair } \\
1\end{array}$} & Pretest_1 & 17.75 & 20 & 1.943 & .434 \\
\hline & Posttest_1 & 30.55 & 20 & 3.501 & .782 \\
\hline
\end{tabular}

Kelompok 1 mengalami peningkatan sebesar 12,80 .

\section{Hasil Pencapaian Perkembangan dengan Media Konvensional}

Sebelum dilaksanakan kegiatan, hasil pencapaian perkembangan dengan media konvensional memiliki nilai rata-rata sebesar 19,65 poin. Setelah dilakukan kegiatan, anak-anak kelompok 1 diukur lagi untuk mendapatkan kemampuan akhir. Rata-rata hasil postes anak-anak kelompok 1 sebesar 22,25 poin. Hasil pembelajaran kelompok 1 berdasarkan kriteria dapat dilihat berdasarkan Tabel 3 .

Tabel 3 Hasil Penggunaan Media Konvensional

\begin{tabular}{clcccc}
\hline \multirow{2}{*}{ Skor } & \multicolumn{2}{c}{ Kriteria } & \multicolumn{2}{c}{ Pretes } & \multicolumn{2}{c}{ Postes } \\
& Jml & $\%$ & $\mathrm{Jml}$ & $\%$ \\
\hline 4 & $\begin{array}{l}\text { Berkembang } \\
\text { Sangat Baik } \\
\text { (BSB) }\end{array}$ & 0 & $0 \%$ & 0 & $0 \%$ \\
& $\begin{array}{l}\text { Berkembang } \\
\text { Sesuai } \\
\text { Harapan } \\
\text { (BSH) }\end{array}$ & 0 & $0 \%$ & 3 & $15 \%$ \\
2 & $\begin{array}{l}\text { Mulai } \\
\text { Berkembang } \\
\text { (MB) }\end{array}$ & 15 & $75 \%$ & 17 & $85 \%$ \\
1 & $\begin{array}{l}\text { Belum } \\
\text { Berkembang } \\
\text { (BB) }\end{array}$ & 5 & $25 \%$ & 0 & $0 \%$ \\
\hline
\end{tabular}

Hasil pengujian menggunakan uji sampel berpasangan (paired sample tests) dinyatakan bahwa hasil pengujian antara hasil pretes menuju postes kelompok 2 mengalami peningkatan. Peningkatan yang terjadi pada kelompok 2, lebih kecil dibanding peningkatan pada kelompok 1 . 
Tabel 4 Hasil Uji Paired Sample Statistics Kelompok 2

Paired Samples Statistics

\begin{tabular}{llcccc}
\hline & & & Std. & Std. Error \\
& & Mean & N & Deviation & Mean \\
\hline Pair & pretest_2 & 19.65 & 20 & 1.926 & .430 \\
1 & posttest_2 & 22.25 & 20 & 2.149 & .480 \\
\hline
\end{tabular}

Berdasarkan Tabel 5.4 nilai rata-rata pretes kelompok 2 yang semula 19,66 berubah menjadi 22,73, jadi kelompok 2 mengalami peningkatan sebesar 3,07.
Perbedaan Hasil Belajar Menggunakan Media CD Interaktif dan Media Konvensional

Rata-rata hasil postes anak-anak kelompok 1 sebesar 30,55 poin, dengan besar peningkatan dari pretes menuju postes sebesar 12,80. Sementara itu hasil postes anak-anak kelompok 2 sebesar 22,25 poin, dengan besar peningkatan dari pretes menuju postes sebesar 2,60 poin. Keefektifan media CD Interaktif dapat dilihat dan dianalisis berdasarkan hasil pengujian melalui output independent sample test pada Tabel 5.

Tabel 5 Hasil Uji Independent Sample Test Postes

\begin{tabular}{|c|c|c|c|c|c|c|c|c|}
\hline \multicolumn{9}{|c|}{ Independent Samples Test } \\
\hline & & \multicolumn{2}{|c|}{$\begin{array}{l}\text { Levene's Test } \\
\text { for Equality of } \\
\text { Variances }\end{array}$} & \multicolumn{5}{|c|}{$\begin{array}{c}\text { t-test for Equality } \\
\text { of Means }\end{array}$} \\
\hline & & $\mathrm{F}$ & Sig. & $\mathrm{t}$ & df & Sig. (2-tailed) & $\begin{array}{c}\text { Mean } \\
\text { Difference }\end{array}$ & $\begin{array}{l}\text { Std. Error } \\
\text { Difference }\end{array}$ \\
\hline \multirow[t]{2}{*}{ Posttest } & $\begin{array}{l}\text { Equal variances } \\
\text { assumed }\end{array}$ & 3.480 & .067 & 9.863 & 58 & .000 & 7.600 & .77053 \\
\hline & $\begin{array}{l}\text { Equal variances } \\
\text { not assumed }\end{array}$ & & & 9.863 & 52.404 & .000 & 7.600 & .77053 \\
\hline
\end{tabular}

Secara umum, hasil penelitian ini dinyatakan bahwa penggunaan media CD Interaktif Kosa Kata Berbudaya Sehat lebih efektif dalam meningkatkan kosa kata anak usia 5-6 tahun dibandingkan menggunakan media konvensional, dengan kata lain media CD Interaktif Kosa Kata Berbudaya Sehat memberikan pengaruh yang signifikan terhadap peningkatan kosa kata untuk anak usia 5-6 tahun.

\section{KESIMPULAN}

Media CD Interaktif Berbudaya Sehat dapat meningkatkan kosa kata anak usia 5-6 tahun, dibuktikan dengan hasil nilai $t_{\text {hitung }}=11,691$ dengan $t_{\text {tabel }}=-2,045$, hal ini menunjukkan ada perbedaan rata- rata sebelum dan sesudah dilaksanakan penelitian pada kelompok 1 .

Media konvensional dapat meningkatkan kosa kata pada anak usia 5-6 tahun, dibuktikan dengan hasil tampak bahwa nilai $t_{\text {hitung }}=11,691$ dengan $t_{\text {tabel }}=$ 2,045, hal ini menunjukkan ada perbedaan rata-rata hasil pretes dan postes kelompok 2.

Hasil belajar anak tentang kosa kata menggunakan media CD Interaktif Kosa Kata Berbudaya Sehat lebih besar dari pada menggunakan media konvensional, dibuktikan melalui uji t Independent bahwa data postes antara kelompok 1 dan kelompok 2 adalah $\mathrm{H}_{0}$ ditolak karena memiliki nilai $t_{\text {hitung }}=9,863$ dengan $t_{\text {tabel }}=$ 2,048 . 
386 | Media Compact Disk Interaktif Berbudaya Sehat untuk Meningkatkan Kosa Kata Anak

\section{DAFTAR PUSTAKA}

Aisyah, S. (2010). Perkembangan dan Konsep Dasar Pengembangan Anak Usia Dini. Jakarta: Universitas Terbuka.

Choirun, N. . (2012). Pengaruh Permainan dan Penguasaan Kosa Kata Terhadap Kemampuan Membaca Permulaan Anak Usia 5-6 Tahun. Pedagogia, 1(2), 131-143.

Currenton, S. M. \& Craig, M. J. 2011. "Shared-reading versus oral story telling associations with preschoolers prosocial skills and problem behaviours". Early Childhood Education Journal,Vol. 181, No.1, Hal. 123-146.

Daryanto. 2010. Ilmu Komunikasi. Jakarta:

Satu Nusa

Erna Sundari. 2013.“Pengaruh Metode Permainan Pola Suku Kata dan Kartu Kata Bergambar Terhadap Kemampuan Membaca Awal Siswa Kelompok B6 TK Negeri 2 Yogyakarta Tahun Ajaran 20132014”. Jurnal Psikologi Terapan dan Pendidikan.

Gerde, Hope K., Gary, E. Bingham., \& Barbara, A. Wasik. 2012."Writing in Early Childhood Classrooms: Guidance for Best Practices". Early Childhood Education Journal.

Gonzalez, Jorge E., Ernest T. Goetz., Robert J. Hall., Tara Payne., Aaron B. Taylor., Minjung Kim., Anita S. McCormick. 2009. "An Evaluation of Early Reading First (ERF) Preschool Enrichment on Language and Literacy Skills". Springer Science + Business

Hill, S. 2011. "Towards Ecologically Valid Assessment in Early Literacy". Early
Childhood Education Journal,Vol. 181, No.2, 165-180.

Mok, M. M. C. dan Lam, H. M. Y. 2011. "Assessment of Language Development of Preschoolers: Validating Morrow's Checklist for Assessing Early Literacy Development". Early Childhood Education Journal,Vol.181, No.2, 203-220.

Nahdayeti. (2011). Permainan Menyusun Huruf Sesuai Dengan Kartu Kata Bergambar Sebagai Upaya Menumbuhkan Kemampuan Membaca Awal Anak Di Taman Kanak-kanak Samudera Padang. Universitas Negeri Padang.

Seniati. (2011). Psikologi Eksperimen. Jakarta: Indeks.

Slavin, R. E., Madden, N. A., Chambers, B., \& Haxby, B. 2014. "Membaca Membuka Pintu Dunia: Program "Success for All" Model yang Jelas dan Kuat untuk Meningkatkan Kemampuan Membaca Anak Sekolah Dasar”. Terjemahan Erick Setiyawati \& Rahmat Fajar. Yogyakarta: Pustaka Pelajar.

Sugiyono. (2010). Metode Penelitian Pendidikan. Bandung: Alfabeta.

Syaodih, N. S. (2009). Metode Penelitian Pendidikan. Bandung: PT. Remaja Rosdakarya Offset.

Wina Sanjaya. 2009. Strategi Pembelajaran: Berorientasi Standar Proses Pendidikan. Jakarta: Prenada Media Group 